\title{
Apoptotic genes expression in $\gamma$-irradiated rats treated with wheat germ oil, zinc and /or bone marrow
}

\author{
Mona A. Mohamed *, Mervat A. Ahmed \\ Biochemistry Division, Chemistry Department, 2Zoology Department, Faculty of Science, Al-Azhar University for Girls \\ *Corresponding author E-mail: mabdelgelel@gmail.com
}

Copyright $\odot 2014$ Mona A. Mohamed, Mervat A. Ahmed. This is an open access article distributed under the Creative Commons Attribution License, which permits unrestricted use, distribution, and reproduction in any medium, provided the original work is properly cited.

\begin{abstract}
Background: Liver inflammation or injury is a hallmark of ionizing radiation. Natural radio-protectors are found in plant materials such as wheat germ oil, in addition to other dietary antioxidants, such as zinc.

Objectives: The present study was designed to evaluate the amelioration of mRNA levels of Bax, bcl-2, p53 and caspase- 3 in the liver of $\gamma$-irradiated rats treated with wheat germ oil, zinc sulphate and/or bone marrow.

Methods: Animals were exposed to an acute single dose of 5Gy whole body irradiation of gamma radiation from Gamma-cell 40 (cesium- 137) source. RNA was extracted from hepatic tissue homogenate and reverse transcribed into cDNA using RT-PCR kit.

Results: A significant elevation was observed in hepatic level of mRNA of Bax and caspase 3, while levels of bcl-2 and p53 mRNA were decreased in irradiated rats as compared to control. A combination of bone marrow and wheat germ oil caused a significant reductions in hepatic mRNA levels of Bax and caspase 3 (3.1 and 1.5-fold, respectively), associated with a significant comparable elevation in hepatic mRNA level of p53 (2.7-fold), compared to the irradiated group.
\end{abstract}

Conclusions: Results obtained from this study suggest that supplementation of wheat germ oil with either BM or zinc to irradiated rats down regulates the proapoptotic genes.

Keywords: Bax, Bcl-2, Caspase-3, P53.

\section{Introduction}

The most common cancer treatment modality promising a cure appeared to be a combination of radiotherapy and chemotherapy. Primary liver tumors or liver metastasis are treated by gamma-irradiation [1]. Following radiotherapy, the risk of normal tissue complication constitutes a significant clinical concern and limits the radiation dose that can be delivered to the patients [2].

Oxidative damage is considered to be one of the most popular and important effects of radiotherapy in the liver that induces generation of reactive oxygen species (ROS), which are per se inducers of apoptosis, and radiotherapy seems to be able to induce an apoptotic program through ROS generation [3].

Gene expression studies have revealed the existence of more than one pathway regulating growth inhibition and apoptotic processes [4]. This antineoplastic effect can be mediated by activation of different target genes such as p21, caspases, Bax and bcl-2 which act as cross-point regulators able to induce or inhibit apoptosis [5].

The development of safe and more effective radio-protectors is very important in view of their potential application during unintended radiation exposure and radiotherapy. Over the past 50 years, the possible radio-protective effects of many synthetic and natural agents have been investigated [6]. Natural radio-protectors are found in plant materials such as oil seed and wheat germ oil [7], which acts as inhibitor of oxidation processes in body tissues and protects cells against the effects of free radicals [8]. In addition, dietary antioxidants, such as zinc, play an important role in cellular antioxidant defense mechanisms. 
Moreover, bone marrow (BM) or peripheral blood stem cell transplantation has gained widespread acceptance for the treatment of certain malignancies. Patients with refractory leukemia's and lymphomas are often conditioned with total body irradiation prior to bone marrow transplantation [9].

The principle objective of the present experiment was to elucidate the effects of a single dose of whole body $\gamma$ irradiation on mRNA levels of Bax, bcl-2, p53 and caspase-3 in the liver of wheat germ oil, zinc sulphate and/or bone marrow treated rats.

\section{Animals and methods}

Chemicals: All chemicals and solvents were of high analytical grade and were purchased from Sigma Chemical Company.

\subsection{Preparation and administration of chemical compounds}

Exactly $100 \mathrm{mg}$ of zinc sulphate was dissolved in $25 \mathrm{ml}$ of distilled water to prepare a stock solution of $4 \mathrm{mg} / \mathrm{ml}$. The solution was prepared weekly and stored in a well stoppered bottle at $4{ }^{\circ} \mathrm{C}$. Zinc sulphate was daily administered to rats by a stainless-steel gavage needle at a dose level of $10 \mathrm{mg} / \mathrm{Kg}$ body weight for 14 successive days before irradiation [10]. Wheat germ oil (WG) was administered to animals by oral gavage at a dose level of $54 \mathrm{mg} / \mathrm{kg}$ body weight [11], $[12]$.

\subsection{Animals and housing}

A total of 120 adult male Swiss albino rats weighing 110-150 g were used throughout this study. Rats were obtained from the animal house of the National Center for Radiation Research and Technology (NCRRT), Atomic Energy Authority, Egypt. The animals were housed in steel mesh cages (5/cage) and maintained for a week-acclimatization period on a commercial pellet diet.

\subsection{Irradiation by gamma rays}

Animals were exposed to an acute single dose of 5Gy whole body irradiation of gamma radiation from Gamma-cell 40 (cesium-137) source belonging to NCRRT at a dose rate of $1.2 \mathrm{rad} / \mathrm{sec}$ [13].

\subsection{Bone marrow transplantation}

Donors and recipients were chosen of the same inbred strain, brother to brother (isologues or synergic or allogeneic transplantation). Femur bones were dissected out and cleaned. The ends of the bones were chipped by a bone nibbling forceps. Then BM was blown out of the femur into isotonic solution under sterilized conditions. Total viable cells of about $75 \times 10^{6} \pm 0.05$ were injected intravenously (i.v.) through the caudal vein one hour after irradiation [14].

\subsection{Experimental design}

Rats were allocated into 2 main groups. Group 1 (Non-irradiated group) which was subdivided into 4 subgroups (10 rats each):

(Con): normal control rats left intact without any treatment. (WG): rats received $54 \mathrm{mg} / \mathrm{Kg}$ body weight wheat germ oil as a single oral dose for 14 successive days. ( $\mathrm{Zn})$ : zinc sulphate (10mg/Kg body weight) was administered to rats as a single oral dose for 14 successive days. $(\mathrm{BM})$ : rats injected with $\mathrm{BM}$ cells $\left(75 \times 10^{6}\right.$ cells $)$ through the caudal vein. Group 2 (Irradiated group) which was further subdivided into 8 subgroups (10 rats each): (R): rats exposed to 5Gy whole body $\gamma$-irradiation. (R+WG): rats treated with $54 \mathrm{mg} / \mathrm{Kg}$ wheat germ oil as a single daily oral dose for 14 successive days before irradiation. $(\mathrm{R}+\mathrm{Zn})$ : rats treated with $10 \mathrm{mg} / \mathrm{Kg}$ zinc sulphate as a single daily oral dose for 14 successive days before irradiation. $(\mathrm{R}+\mathrm{Zn}+\mathrm{WG})$ : rats treated with $10 \mathrm{mg} / \mathrm{Kg}$ zinc sulphate and $54 \mathrm{mg} / \mathrm{Kg}$ wheat germ oil of body weight as a single daily oral dose for 14 successive days before irradiation. (R+BM): rats exposed to $5 \mathrm{~Gy}$ gamma rays and received $\mathrm{BM}\left(75 \times 10^{6}\right.$ cells) one hour after irradiation. ( $\left.\mathrm{R}+\mathrm{BM}+\mathrm{WG}\right)$ : rats treated with $54 \mathrm{mg} / \mathrm{Kg}$ wheat germ oil as a single daily oral dose for 14 successive days before irradiation and received BM cells one hour after irradiation. $(\mathrm{R}+\mathrm{BM}+\mathrm{Zn})$ : rats treated with $10 \mathrm{mg} / \mathrm{Kg}$ zinc sulphate as a single daily oral dose for 14 successive days before irradiation and received $\mathrm{BM}$ cells one hour after irradiation. $(\mathrm{R}+\mathrm{BM}+\mathrm{Zn}+\mathrm{WG})$ : rats treated with zinc sulphate and wheat germ oil $(10 \mathrm{mg} / \mathrm{Kg}$ and $54 \mathrm{mg} / \mathrm{Kg}$, respectively) as a single daily oral dose for 14 successive days before irradiation and received BM cells one hour after irradiation. All rats were free access to tap water and diet and sacrificed after 14 days of irradiation. 


\subsection{Liver sampling and processing}

At the end of the experimental period, animals in all groups were fasted overnight, weighed and sacrificed by decapitation. Livers were excised, rinsed with shield saline, weighed and rapidly frozen in liquid nitrogen then stored at $-70^{\circ} \mathrm{c}$ until assayed. RNA was extracted from hepatic tissue homogenate using RNeasy Purification Reagent (Qiagen, Valencia, CA). The extracted RNA was reverse transcribed into cDNA using RT-PCR kit (Stratagene, USA). cDNA was generated from $5 \mu \mathrm{g}$ of total RNA extracted with $1 \mu \mathrm{l}(20 \mathrm{pmol})$ antisense primer of each gene and $0.8 \mu 1$ superscript AMV reverse transcriptase for $60 \mathrm{~min}$ at $37^{\circ} \mathrm{c}$. For PCR, $4 \mu \mathrm{l} \mathrm{cDNA}$ were incubated with $30.5 \mu 1$ water, $4 \mu 125 \mathrm{mM}$ $\mathrm{MgCl} 2,1 \mu \mathrm{l}$ dNTPs $(10 \mathrm{mM}), 5 \mu \mathrm{l} 10 \mathrm{x}$ PCR buffer, $0.5 \mu \mathrm{l}(2.5 \mathrm{U})$ Taq polymerase and $2.5 \mu \mathrm{l}$ of each primer containing $10 \mathrm{pmol}$ (primer sequences were shown in table 1). The reaction mixture was subjected to 40 cycles of PCR amplification as follows: denaturation at $95^{\circ} \mathrm{c}$ for $1 \mathrm{~min}$, annealing at $67^{\circ} \mathrm{c}$ for $1 \mathrm{~min}$ and extension at $72^{\circ} \mathrm{c}$ for $2 \mathrm{~min}$. A real time- PCR mixture was then prepared as follows: $25 \mu 1$ SYBR Green Mix (2x), $0.5 \mu 1$ cDNA, $2 \mu 1$ primer pair mix (5pmol/ $\mu \mathrm{l}$ each primer), $22.5 \mu \mathrm{H} 2 \mathrm{O}$. According to the amplification procedure, relative expression of each studied gene was calculated according to the following the formula: densitometrical units of each studied gene/densitometrical units of $\beta$-actin. Beta actin was amplified with the same run of tested genes as housekeeping gene to detect RNA integrity.

Table 1: The Oligonucleotide Primers Sequence:

\begin{tabular}{|c|c|c|}
\hline Gene & \multicolumn{2}{|c|}{ Primer sequence } \\
\hline Bax & Forward & 5' GTTGCCCTCTTCTACTTTG 3' \\
\hline$\left(N M \_017059.1\right)^{*}$ & Reverse & 5' AGCCACCCTGGTCTTG 3' \\
\hline bcl-2 & Forward & 5' CGGGAGAACAGGGTATGA 3' \\
\hline$\left(\right.$ NM_016993.1) ${ }^{*}$ & Reverse & 5' CAGGCTGGAAGGAGAAGAT 3' \\
\hline p53 & Forward & 5'-GTTCCGAGAGCTGAATGAGG-3' \\
\hline [15] & Reverse & 5'-TTTTATGGCGGGACGTAGAC-3' \\
\hline caspase 3 & Forward & 5'- ATGGACAACAACGAAACCTC-3' \\
\hline$(\mathrm{A} 062449)^{*}$ & Reverse & 5'-TTAGTGATAAAAGTACAGTTCTT-3' \\
\hline$\beta$ actin & Forward & 5' TGCTGGTGCTGAGTATGTCG 3' \\
\hline$\left(\mathrm{NM} \_017008\right)^{*}$ & Reverse & 5' TTGAGAGCAATGCCAGCC 3' \\
\hline
\end{tabular}

* Gene bank accession

\section{Statistical analysis}

All results were expressed as the mean \pm SE. Statistical analysis was performed with Statistical Package for the Social Science for Windows (SPSS, version 11.0, Chicago, IL, USA). The data were analyzed by one-way Analysis of Variance (ANOVA). To compare the difference among the groups, post hoc testing was performed by Bonferroni test. The p-value less than 0.05 were considered statistically significant [16] (Dawson and Trapp, 2001).

\section{Results}

Table 2 shows that whole body irradiation with gamma rays caused a significant elevation in hepatic mRNA of Bax and caspase $3(\mathrm{p}<0.001)$, compared to the control group. On contrary, mRNA levels of bcl-2 and p53 were significantly reduced $(\mathrm{p}<0.001)$ in irradiated rats, compared to normal non-irradiated animal.

In spite the pronounced up regulation of Bax and caspase 3 genes and down regulation of bcl-2 gene produced by wheat germ oil supplementation in non-irradiated rats, compared to control rats, multiple comparison analysis showed that wheat germ oil gave rise to a significant decrease in mRNA levels of Bax and caspase $3(p<0.001)$, while expression of bcl-2 was increased in irradiated treated rats, compared to radiated group. Non-irradiated rats supplemented with zinc sulphate revealed a comparable reduction in mRNA levels of bcl-2 and p53 and significant elevation in caspase 3 mRNA, compared to normal control rats. Treatment of irradiated animals with zinc sulphate caused a notable increase in mRNA levels of bcl-2 and p53, while caused significant reduction in caspase 3, compared to irradiated animals. Hepatic mRNA levels of Bax and caspase 3 were significantly elevated, while levels of bcl-2 and p53 were reduced in non-irradiated rats treated with BM, compared to controls. Significant decreases were recorded in mRNA levels of Bax and caspase 3 after treatment of irradiated rats with BM, whereas bcl-2 and p53 were increased, compared to irradiated rats. None of the foregoing treatments significantly reached to the control levels.

Multiple comparison analysis showed that treatment of irradiated rats with a combination of zinc sulphate and wheat germ oil caused a more pronounce reductions in hepatic mRNA levels of Bax and caspase 3 (3 and 4.9-fold, respectively), while more pronounced elevation was recorded in mRNA level of p53 which reached 2.8-fold, compared to the irradiated group. Combination of zinc sulphate and wheat germ oil treatment caused a slight but significant up regulation of bcl-2 (2.1-fold) (fig. 1). Figure 3 also demonstrates that treatment of irradiated rats with a combination of $\mathrm{BM}$ and wheat germ oil caused a significant reductions in hepatic mRNA levels of Bax and caspase 3 (3.1 and 1.5-fold, 
respectively), associated with a significant comparable elevation in hepatic mRNA level of p53 (2.7-fold), compared to the irradiated group.

Figure 2 reveals that supplementation of wheat germ oil with either BM or zinc to irradiated rats lowered significantly $\mathrm{Bax} / \mathrm{bcl}-2$ ratio, compared to irradiated group.

Table 2: Hepatic Mrna Levels of Bax, Bcl-2, P53 and Caspase 3 in Different Studied Groups (Mean \pm SE).

\begin{tabular}{|c|c|c|c|c|c|}
\hline Groups & & Bax & bcl-2 & $\mathrm{p} 53$ & caspase 3 \\
\hline \multirow{4}{*}{ Non-irradiated } & 1-Con & $0.11 \pm 0.015$ & $1.53 \pm 0.27$ & $1.59 \pm 0.52$ & $0.075 \pm 0.005$ \\
\hline & $2-\mathrm{WG}$ & $0.57 \pm 0.09^{* \#}$ & $0.4 \pm 0.04^{* \#}$ & $1.40 \pm 0.20^{\#}$ & $0.30 \pm 0.14^{* \#}$ \\
\hline & $3-\mathrm{Zn}$ & $0.14 \pm 0.05^{\#}$ & $0.59 \pm 0.03^{* \#}$ & $0.69 \pm 0.01^{*}$ & $0.20 \pm 0.03^{* \#}$ \\
\hline & 4-BM & $0.22 \pm 0.03^{\#}$ & $0.88 \pm 0.04^{* \#}$ & $1.10 \pm 0.20^{* \#}$ & $0.23 \pm 0.02^{* \#}$ \\
\hline \multirow{8}{*}{ Irradiated } & $5-\mathrm{R}$ & $0.80 \pm 0.16^{*}$ & $0.19 \pm 0.07^{*}$ & $0.44 \pm 0.38^{*}$ & $0.54 \pm 0.14^{*}$ \\
\hline & $6-\mathrm{R}+\mathrm{WG}$ & $0.40 \pm 0.02^{* \#}$ & $0.39 \pm 0.07^{* \#}$ & $0.56 \pm 0.07^{*}$ & $0.35 \pm 0.07^{* \#}$ \\
\hline & $7-\mathrm{R}+\mathrm{Zn}$ & $0.71 \pm 0.08^{*}$ & $0.82 \pm 0.14^{* \#}$ & $0.78 \pm 0.14^{* \#}$ & $0.26 \pm 0.07^{* \#}$ \\
\hline & $8-\mathrm{R}+\mathrm{Zn}+\mathrm{WG}$ & $0.27 \pm 0.07^{* \#}$ & $0.39 \pm 0.07^{* \#}$ & $1.25 \pm 0.05^{\text {*\# }}$ & $0.11 \pm 0.02^{* \#}$ \\
\hline & 9-R+ BM & $0.58 \pm 0.03^{* \#}$ & $1.01 \pm 0.02^{* \#}$ & $0.85 \pm 0.18^{* \#}$ & $0.41 \pm 0.23^{*}$ \\
\hline & $10-\mathrm{R}+\mathrm{BM}+\mathrm{WG}$ & $0.26 \pm 0.14^{* \#}$ & $0.83 \pm 0.11^{* \#}$ & $1.19 \pm 0.20^{* \#}$ & $0.36 \pm 0.13^{* \#}$ \\
\hline & $11-\mathrm{R}+\mathrm{BM}+\mathrm{Zn}$ & $1.00 \pm 0.20^{* \#}$ & $1.00 \pm 0.02^{* \#}$ & $1.00 \pm 0.08^{* \#}$ & $0.50 \pm 0.10^{*}$ \\
\hline & $12-\mathrm{R}+\mathrm{BM}+\mathrm{Zn}+\mathrm{WG}$ & $0.46 \pm 0.18^{* \#}$ & $0.22 \pm 0.03^{*}$ & $0.98 \pm 0.04^{* \#}$ & $0.35 \pm 0.08^{* \#}$ \\
\hline
\end{tabular}

* Significant vs con, \# significant vs rad.
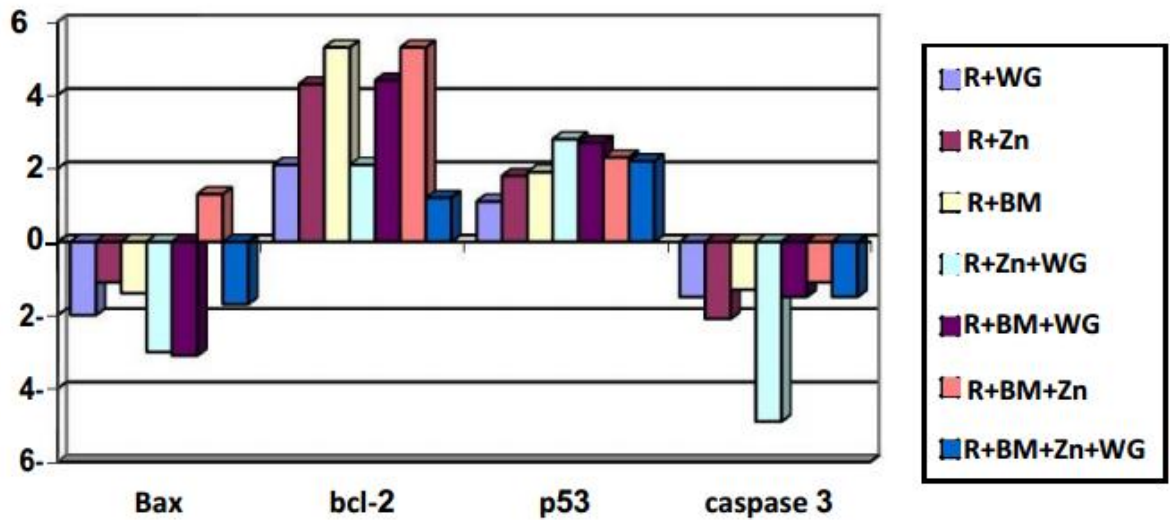

Fig. 1: Relative Fold Change in Hepatic Pro- and Anti-Apoptotic Gene Expression Profiles of Irradiated Rats Treated with the Different Modalities.

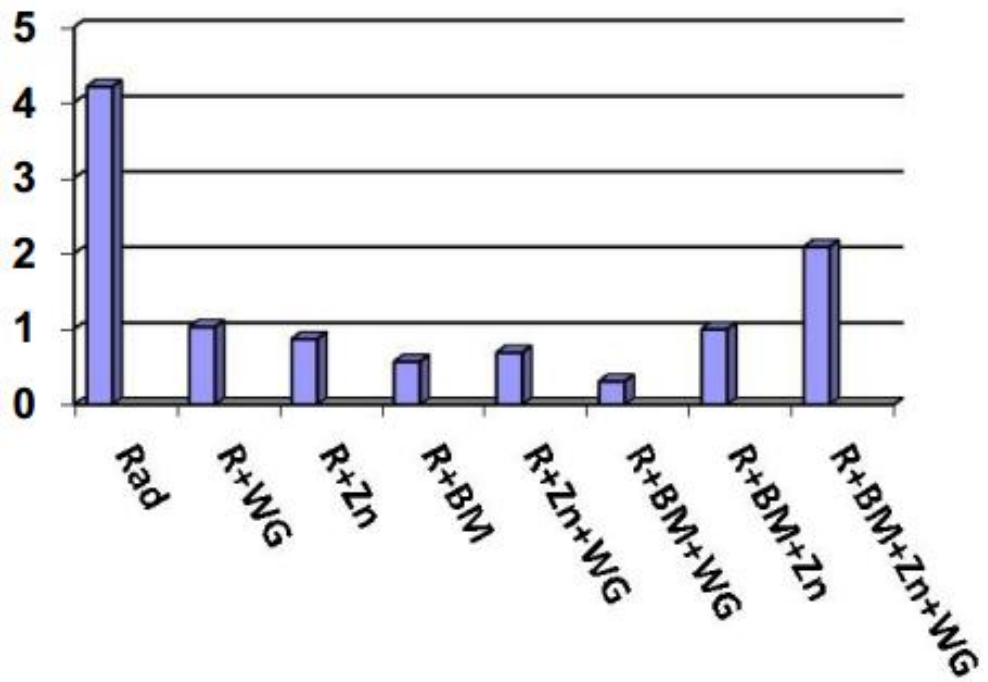

Fig. 2: The Ratio of Bax To Bcl-2 in Irradiated Rats and Those Treated with the Different Modalities.

\section{Discussion}

Exposure to ionizing radiation results in a complex set of responses whose onset, nature, and severity is a function of both total radiation dose and quality [17]. Three models of radiation-induced apoptotic pathways have been proposed. Firstly, radiation-induced DNA damage may initiate apoptosis via p53 dependent mechanism. Secondly, the biochemical changes such as an increase in the generation of reactive oxygen species (ROS). Thirdly, interaction of 
ionizing radiation with cellular membranes induces rapid sphingomyelin hydrolysis to ceramide [18]. Our previous study [19] revealed a significant reduction in blood reduced glutathione (GSH) as well as marked elevation in serum malondialdehyde (MDA) levels in irradiated rats, compared to control. One possible mechanism of cell and tissue damage after irradiation is the production of reactive oxygen species (ROS) in irradiated cells and tissues.

In the present study, rats exposed to whole body $\gamma$-irradiation resulted in over expression of Bax and caspase 3 genes, while mRNA level of bcl-2 was decreased. Reactive oxygen species, which were originally characterized in terms of their harmful effects on cells are increasingly implicated in various cell fate decisions and signal transduction pathways [20]. Reactive oxygen intermediates induced by ionizing radiation can trigger mitochondrial pathway to release caspase-activating-factors. Therefore, oxidative stress may play a direct role in radiation-induced apoptosis [21].

The main role of bcl-2 gene product in the process of apoptosis is based on its ability to inhibit ion conductive channels formation in mitochondrial membrane, and in most cases to prevent mitochondrial disruption and the release of cytochrome c. Therefore, a down regulation of anti-apoptotic bcl-2 may cooperate to accelerate the signaling of postmitotic apoptosis in $\gamma$-irradiated rats. The Bax/bcl-2 ratio indicates the relative amounts of pro- and anti-apoptotic proteins of the BCL-2 family. The present results revealed significant elevation in the ratio of mRNA levels of Bax to bcl-2 in irradiated group, compared to non-radiated animals. This increased ratio may be considered an indicator of enhanced cell death in response to reactive oxygen species as reported by Debatin, [22].

Vaseva and Moll [23] revealed that in normal mice exposed to whole body $\gamma$-irradiation (5 or $10 \mathrm{~Gy}$ ) mitochondrial p53 accumulation occurs in radiosensitive organs like thymus, spleen and testis, but not in radio-resistant organs like liver and kidney. These results are in line with our results which show decrease in mRNA level of p53 in irradiated rats.

In fact, the choice of response to p53 is strongly influenced by the cell type, the cellular environment, and the type of signal. Komarova et al., [24] demonstrated that the upstream signals that direct induction of p53 are controlled in a tissue-specific manner. Marchenko et al., [25], demonstrate that during p53-dependent apoptosis, a fraction of stressstabilized wild-type p53 rapidly translocates to the mitochondrial outer membrane. Alternatively, p53 up regulates the expression of Bax, a regulator of mitochondrial membrane permeabilization, and induce apoptosis by the release of cytochrome $\mathrm{c}$ from the mitochondria [26]. This translocation occurs during p53-dependent apoptosis, however there are still many experiments show that radiation-induced apoptosis occur independently of the function and presence of p53 [27], [28].

Since oxidative damage is considered one of the most popular and important effects of radiotherapy in the liver. The involvement of free radical scavengers in protecting against radiation damage was highlighted when scientists found that whole body radiation decreased the total antioxidant capacity of organisms [29].

Surprisingly treatment of irradiated rats with single or combined doses of the tested modalities (wheat germ oil, zinc and bone marrow) decreased the harmful effects of radiation.

Multiple comparison analysis revealed that treatment of irradiated rats with a combination of zinc sulphate and wheat germ oil was the most effective model, while combination of bone marrow and wheat germ oil was the second effective model. In addition to improving the expression of the studied genes to near the control levels, these models directed hepatic cells toward cell survival as noticed by the decreased Bax/bcl-2 ratio.

Wheat germ is a rich source of B complex vitamins, with wheat germ oil being the richest source of tocopherols [30], [31]. This oil is a source of easily assailable vitamin E which acts as inhibitor of oxidation processes in body tissues. It protects cells against the effects of free radicals, which are potentially damaging by products of the body's metabolism [8].

$\mathrm{Zn}$ is critical for the functional and structural integrity of eukaryotic cells and tissues and is required for events as diverse as gene expression, DNA synthesis and enzymatic catalysis [32]. Zn has properties advantageous for a role in cytoprotection as it can protect proteins and nucleic acids from oxidation and degradation. These antioxidant properties of $\mathrm{Zn}$ were probably important in the context of regulation of apoptosis because cells were becoming damaged by oxidative stress. Zn did not block the activity of caspase-3 to cleave its cellular substrates, but rather blocked the mechanism by which caspase-3 is activated from the inactive zymogen precursor [33]. In addition, zinc has been shown to increase the ratio of bcl-2 to bax in U-937 cells pretreated with hydrogen peroxide. This increased ratio is an indicator of enhanced cell survival [34].

Bone marrow is the major reservoir for adult organ-specific stem cells, including endothelial progenitor cells, hematopoietic stem cells, and mesenchymal stem cells [35]. Consequently, it is reasonable to propose that BM mesenchymal stem cells may be locally activated in livers of the irradiated rats and compensated the damaged cells. However, this possibility still needs to be confirmed by subsequent studies.

In conclusion, we demonstrated that total body irradiation with $\gamma$-ray induced disturbances in pro- and anti-apoptotic genes. We speculate that the observed improvement in the studied parameters in groups treated with Zn and WG oil, either individually or combined may be due to their antioxidant effects. Taking into account that BM-derived cells are responsible of maintaining, generating, and replacing differentiated cells as a consequence of physiological cell turnover or tissue damage due to injury, the data obtained by this study suggested that this is the main cause of the good results in combination between BM and antioxidants.

There is no conflict of interest including any financial, personal or other relationships with other people or organizations within 3 years of beginning the submitted paper. 


\section{References}

[1] A. Malik, N. Naz, S Khan, H. Christiansen, G. Ramadori, Effect of gamma-radiation on healthy rat liver and gene expression of chemokines: In vivo and in vitro studies, J Clin Oncol 28 (2010) suppl e21107.

[2] C.K. Nair, V. Salvi, T.V. Kagiya, R. Rajagopalan, Relevance of radioprotectors in radiotherapy: studies with tocopherol monoglucoside, J Environ Pathol Toxicol Oncol 23 (2004) 153-60.

[3] Y. Guney, A. Hicsonmez, C. Uluoglu, H.Z. Guney, U. Ozel Turkcu, G. Take, B. Yucel, G. Caglar, A. Bilgihan, D. Erdogan, M. Nalca Andrieu, C. Kurtman, H. Zengil, Melatonin prevents inflammation and oxidative stress caused by abdominopelvic and total body irradiation of rat small intestine, Braz J Med Biol Res, 40 (2007) 1305-14. http://dx.doi.org/10.1590/S0100-879X2006005000156.

[4] D. Chendil, R. Oakesm, R.A. Alcock, N. Patel, C. Mayhew, M. Mohiuddin, V.S. Gallicchio, M.M. Ahmed, Low dose fractionated radiation enhances the radio sensitization effect of paclitaxel in colorectal tumor cells with mutant p53, Cancer 89 (2000) 1893-1900. http://dx.doi.org/10.1002/1097-0142 (20001101)89:9<1893: AID-CNCR4>3.3.CO; 2-2.

[5] B. Bucci, S. Misiti, A. Cannizzaro, R. Marchese, G.H. Raza, R. Miceli, A. Stigliano, D. Amendola, O. Monti, M. Biancolella, F. Amati, G. Novelli, A. Vecchione, E. Brunetti, U. De Paula, Fractionated ionizing radiation exposure induces apoptosis through caspase-3 activation and reactive oxygen species generation, Anticancer Res 26 (2006) 4549-4558.

[6] W. Xu, F. Yang, X. Shen, S. Fan, O. Liu, D. Wang, Polysaccharide isolated from Parmelia tinctorumameliorates ionizing irradiation-induced damage in mice, J Radiat Res (2014). doi: 10.1093/jrr/rrt224. http://dx.doi.org/10.1093/jrr/rrt224.

[7] D.K. Singh, L. Li, T.D. Porter, Policosanol inhibits cholesterol synthesis in hepatoma cells by activation of AMP-kinase, J Pharmacol Exp Ther 318(2006) 1020-6. http://dx.doi.org/10.1124/jpet.106.107144.

[8] A.H. Barakat, O.A. Abbas, S. Ayad, A.M. Hassan, Evaluation of radioprotective effects of wheat germ oil in male rats, J Am Sci 7(2011) 66473.

[9] E.H. Kajioka, M.L. Andres, J. Li, X.W. Mao, M.F. Moyers, G.A. Nelson, J.M. Slater, D.S.Gridley, Acute effects of whole-body proton irradiation on the immune system of mouse, Rad Res 14(2000) 153-187.

[10] N. Roosen, F. Doz, K. Yeomansk, M. Rosenblum, Effect of pharmacological doses of zinc on the therapeutic index of brain tumor chemotherapy with carmostine, Cancer Chemother Pharmacol 34(1994) 385-392. http://dx.doi.org/10.1007/BF00685562.

[11] B. Reddy, Y. Hirose, L. Cohen, B. Simi, I. Cooma, C. Rao, Preventive potential of wheat bran fractions against experimental colon carcinogenesis: implications for human colon cancer prevention, Cancer Res 60(2000) 4792.

[12] V. Paranich, O. Cherevko, N. Frolova, A. Paranich, The effect of wheat germ oil on the antioxidant system of animals, Lik Sprava 2(2000) 404.

[13] O.M. Ashry, E.M. Hussein, S.F. Salama, Boosting of antioxidant defense by interferon-alpha in irradiated bone marrow transplantation rats, Egypt J Rad Sci 22(2009) 19-33.

[14] A. Decleave, G.B. Gerber, M. Leonard, M. Lambiet-Collier, A. Sassen, J.R. Maisin, Regeneration of thymus, spleen and bone marrow in Xirradiated AKR mice, Rad Res 51(1972) 318-332. http://dx.doi.org/10.2307/3573613.

[15] P. Longxi, F. Buwu, W. Yuan, G. Sinan, Expression of p53 in the effects of artesunate on induction of apoptosis and inhibition of proliferation in rat primary hepatic stellate cells, PLoS One 6(2011) e26500. http://dx.doi.org/10.1371/journal.pone.0026500.

[16] B. Dawson, R.G. Trapp, Basic and clinical biostatistics, PBL. Lange Medical Books/McGraw-Hill, USA (2001)

[17] M.H. Barcellos-Hoff, How do tissue respond to damage at the cellular level? The role of cytokines in irradiated tissues, Rad Res 150 (5 Suppl) (1998) S109-20. http://dx.doi.org/10.2307/3579813.

[18] A. Haimovitz-Friedman, C.C. Kan, D. Ehleiter, R.S. Persaud, M. McLoughlin, Z. Fuks, R.N. Kolesnick, and Ionizing radiation acts on cellular membranes to generate ceramide and initiate apoptosis, J Exp Med 180(1994) 525-535. http://dx.doi.org/10.1084/jem.180.2.525.

[19] M.A. Ahmed, M.A. Mohamed, M.G. Soliman, Y.H. Abd Al-Naby, Monitoring the expression of some cell adhesion molecules and serum levels of IL-6 and TNF- $\alpha$ in irradiated rats treated with wheat germ oil, zinc and bone marrow, J Pharm Biomed Sci 4(2014) 755-762.

[20] K.M. Holmström, T. Finkel, Cellular mechanisms and physiological consequences of redox-dependent signaling, Nature Reviews Molecular Cell Biology 15(2014) 411-421. http://dx.doi.org/10.1038/nrm3801.

[21] N. Shinomiya, New concepts in radiation-induced apoptosis: 'premitotic apoptosis' and 'postmitotic apoptosis', J Cell Mol Med 5(2001) 240253 http://dx.doi.org/10.1111/j.1582-4934.2001.tb00158.x.

[22] K.M. Debatin, Apoptosis pathways in cancer and cancer therapy. A review, Cancer Immunol Immunother 53(2004) 153-159. http://dx.doi.org/10.1007/s00262-003-0474-8.

[23] A.V. Vaseva, U.M. Moll, The mitochondrial p53 pathway, Biochimica ET Biophysica Acta (2009) 1787: 414-420 http://dx.doi.org/10.1016/j.bbabio.2008.10.005.

[24] E.A. Komarova, K. Christov, A.I. Faerman, A.V. Gudkov, Different impact of p53 and p21 on the radiation response of mouse tissues, Oncogene 19(2000) 3791-3798 http://dx.doi.org/10.1038/sj.onc.1203717.

[25] N.D. Marchenko, A. Zaika, U.M. Moll, Death signal-induced localization of p53 protein to mitochondria. A potential role in apoptotic signaling, J Biol Chem 275(2000) 16202-16212. http://dx.doi.org/10.1074/jbc.275.21.16202.

[26] L. Vuong, S.M. Conley, M.R. Al-Ubaidi, Expression and role of p53 in the retina, Invest Ophthalmol Vis Sci 53(2012) $1362-71$. http://dx.doi.org/10.1167/iovs.11-8909.

[27] A. Narti, F. Hafezi, N. Lansel, M.E. Hegi, A. Wenzel, C. Grimm, G. Niemeyer, C.E. Reme, Light-induced cell death of retinal photorecptors in the absense of p53, Investigative Ophthalmology \&Visual Science 39(1998) 846-849.

[28] L.D. Shostak, J. Ludlow, J. Fisk, S. Pursell, B.J. Rimel, D. Nguyen, J.D. Rosenblatt, V. Planelles, Roles of p53 and caspases in the induction of cell cycle arrest and apoptosis by HIV-1 vpr, Exp Cell Res 251(1999) 156-165. http://dx.doi.org/10.1006/excr.1999.4568.

[29] A. Cetin, L. Kaynar, I. Kocyigit, S.K. Hacioglu, R. Saraymen, A. Ozturk, O. Orhan, O. Sagdic, The effect of grape seed extract on radiationinduced oxidative stress in the rat liver, Turk J Gastroenterol 19(2008) 92-98.

[30] M.K. Jensen, P. Koh-Banerjee, F.B. Hu, M. Franz, L. Sampson, Intakes of whole grains, bran and germ and the risk of coronary heart disease in men, Am J Clin Nutr 80(2004) 1492 - 1499.

[31] R.H. Lui, Whole grain phytochemicals and health, J Cereal Sci 46(2007) 207-219. http://dx.doi.org/10.1016/j.jcs.2007.06.010.

[32] F. Chai, A.Q. Truong-Tran, L.H. Ho, P.D. Zalewski, Regulation of caspase activation and apoptosis by cellular zinc fluxes and zinc deprivation: A review, Immunol Cell Biol 77(1999) 272-278 http://dx.doi.org/10.1046/j.1440-1711.1999.00825.x.

[33] A. Takahashi, E.S. Alnemri, Y.A. Lazebnik, T. Fernandes-Alnemri, G. Litwack, R.D. Moir, R.D. Goldman, G.G. Poirier, S.H. Kaufmann, W.C. Earnshaw, Cleavage of lamin A by Mch2 alpha but not CPP32: multiple interleukin 1 beta-converting enzyme-related proteases with distinct substrate recognition properties are active in apoptosis, PNAS 93(1996) 8395-400. http://dx.doi.org/10.1073/pnas.93.16.8395.

[34] Y. Fukamachi, Y. Karasaki, T. Sugiura, H. Itoh, T. Abe, K. Yamamura, K. Higashi, Zinc suppresses apoptosis of U937 cells induced by hydrogen peroxide through an increase of the bcl-2/bax ratio, Biochem Biophys Res Commun 246(1998) 364-369. http://dx.doi.org/10.1006/bbrc.1998.8621.

[35] B.P. Campagnaro, C.L. Tonini, B.V. Nogueira, D.E. Casarini, E.C. Vasquez, S.S. Meyrelles, DNA Damage and Augmented Oxidative Stress in Bone Marrow Mononuclear Cells from Angiotensin-Dependent Hypertensive Mice, Inter J Hypertens 2013(2013) 1-10. http://dx.doi.org/10.1155/2013/305202. 